\title{
Reconstruction and Scientific Explanation of Akar Kuning (Arcangelisia flava Merr.) From West Sumatra as Ethnomedicine and Source of Science Learning
}

\author{
Skunda Diliarosta ${ }^{1, *}$, Sudarmin $^{2}$, Annisa Efendi ${ }^{3}$, Dwisari Dillasamola ${ }^{1}$, Biomechy Oktomalioputri ${ }^{4}$, Rehani \\ Ramadhani ${ }^{4}$
}

\section{Skunda Diliarosta ${ }^{1, *}$, Sudarmin $^{2}$, Annisa Efendi ${ }^{3}$, Dwisari Dillasamola' ${ }^{1}$, Biomechy Oktomalioputri ${ }^{4}$, Rehani Ramadhani $^{4}$}

'Department of Science Education, Universitas Negeri Padang, INDONESIA. ${ }^{2}$ Chemistry Department, Faculty of Mathematics and Natural Science, Semarang State University, INDONESIA.

${ }^{3}$ Pharmacology department, Faculty of Pharmacy, Andalas University, INDONESIA. ${ }^{4}$ Histology Department, Faculty of Medicine, Andalas University, INDONESIA.

\section{Correspondence}

\section{Skunda Diliarosta}

Department of Science Education,

Universitas Negeri Padang, INDONESIA.

E-mail: skunda@fmipa.unp.ac.id

\section{History}

- Submission Date: 29-08-2020;

- Review completed: 12-10-2020;

- Accepted Date: 05-10-2020

DOI : 10.5530/pj.2021.13.29

Article Available online http://www.phcogj.com/v13/i1

\section{Copyright}

(C) 2021 Phcogj.Com. This is an open access article distributed under the terms of the Creative Commons Attribution 4.0 International license.

\begin{abstract}
Indonesia is one of the countries that has the largest tropical forest land in the world, this makes Indonesia rich in diversity of flora and fauna. This diversity produces a variety of cultures, traditions and local wisdom. One of the local wisdoms of the people of West Sumatra is the use and utilization of the biodiversity around it as a medicine for various diseases. The type of medicinal plant that is the focus of this research is the type of Akar Kuning plant (Arcangelisia flava Merr.). This research is an educational research conducted using an ethnoscience approach, meaning that it is based on the indigenous knowledge of the local community. This study aims to reconstruct knowledge from a cultural / community perspective in the health sector. which later will become a knowledge with scientific explanation. The data were obtained through direct observation to the research location regarding indigenous knowledge about the Akar Kuning plant and also based on laboratory test data on antibacterial activity carried out in the biology laboratory of Semarang State University. All data obtained will be analyzed and also strengthened by various sources. The analysis concluded that the Akar Kuning (Arcangelisia flava Merr.) Plant contains bioactive compounds that act as antibacterials, thus inhibiting bacterial growth. This is evidenced by the inhibition zone diameter data produced during laboratory tests showing the results that the Yellow Root plant extract (Arcangelisia flava Merr.)

Key words: Reconstruction, Akar Kuning (Arcangelisia flava Merr.), Scientific explanation, Ethnoscience.
\end{abstract}

\section{INTRODUCTION}

Indonesia is one of the countries that has the largest tropical forest land in the world. ${ }^{1}$ With the existence of tropical forests, Indonesia has high biodiversity and is included in the eight mega biodiversity countries in the world, both flora and fauna. ${ }^{2}$ The distribution of flora and fauna that are owned by Indonesia reaches a very wide area and there are also several types that are endemic, meaning that these species can only grow or be found in one place.

The ethnic diversity in Indonesia has resulted in various cultures, traditions and local wisdom. One of the local wisdoms is the use of the diversity around it as a medicine for various diseases. ${ }^{3}$ So far, the efficacy of various plants has been known and has been used from generation to generation by the community as medicinal plants that have the ability to cure various diseases, it's just that people do not yet know what substances are contained in these plants. and the use of medicinal plants in Indonesia is not just knowledge about their properties but further, by proving the content of the compounds, the use of these medicinal plants can be developed in the pharmaceutical industry.

One type of medicinal plant that is the focus of this research is a type of Akar Kuning plant (Arcangelisia flava Merr.) Which mostly grows in the Rimbo Panti Nature Reserve Forest. Actually this Akar Kuning plant is an endemic plant from Kalimantan, especially known to have a lot of pharmacological potential, including as an antiviral. ${ }^{4}$

The use of the Akar Kuning plant (Arcangelisia flava Merr.) For the community is as a jaundice medicine, anti-malaria, and cancer medicine. In its use, ordinary people consume it once a day until the illness is healed, if the illness is quite severe, they can drink it 2 times a day. This rule applies to all diseases.

It is known that the Akar Kuning plant contains various bioactive compounds, one of the most famous being berberine. Akar Kuning are lianas, up to $20 \mathrm{~m}$ long, living in lowlands up to $800 \mathrm{~m}$ above sea level (asl). The leaves are thick and strong like skin, oval shaped, blunt not sharp, leaf width 7 $\mathrm{cm}$ to $20 \mathrm{~cm}$, glossy top surface and long stalk. The flowers are housed in two small sizes arranged in a series of glabrous $20 \mathrm{~cm}$ to $50 \mathrm{~cm}$, greenish-white or yellowish-white with buds. ${ }^{5}$ The wood is yellow, its purpose is to boil the stems to treat jaundice, digestion, intestinal worms, fever, and canker sores. The fruit, which is yellow in color, can be used to anesthetize fish.

This study uses an ethnomedicine approach. Ethnomedicine is the perception and conception

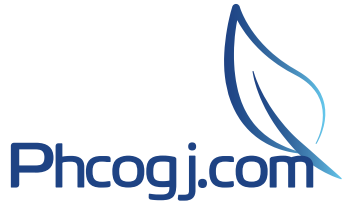

Cite this article: Diliarosta S, Sudarmin, Efendi A, Dillasamola D, Oktomalioputri B, Ramadhani R. Reconstruction and Scientific Explanation of Akar Kuning (Arcangelisia flava Merr.) From West Sumatra as Ethnomedicine and Source of Science Learning. Pharmacog J. 2021;13(1): 206-11.

Pharmacognosy Journal, Vol 13, Issue 1, Jan-Feb, 2021 
of local people in understanding health or research that addresses traditional medical systems. ${ }^{6}$ The purpose of conducting this ethnomedicine research is to see from a cultural / community point of view in the health sector, which will later be reconstructed into knowledge with scientific explanations. The need to reconstruct indigenous peoples' knowledge is known as scientific knowledge reconstruction.?

Ethnomedicin study is one way to document and collect information about the use of plants as medicinal substances by people in West Sumatra. This article will reveal what ethnomedicin studies in Indonesia are and their research methods. It is hoped that this paper will be used as a reference in developing ethnomedicine research in Indonesia.

Documenting the use of medicinal plants is a race against time, this is due to the excessive harvesting of biological resources (over exploitation) and of course this has an impact on the loss of biodiversity in Indonesia. Kartawinata (2010) stated that the rate of species loss is in line with the rate of loss of local knowledge. ${ }^{8}$ Besides ethnomedicine, this research also touches on ethnopharmacology, which is the study of the use of plants that have pharmacological effects that are related to treatment and health care by certain communities., ${ }^{9,10}$

\section{RESEARCH METHODS}

\section{Types of research}

This research is a qualitative research followed by an experiment, the qualitative method is descriptive analysis. This qualitative research uses an ethnoscience approach, ${ }^{7}$ which is used to reconstruct and explain scientific knowledge based on people's beliefs about the Akar Kuning plant (Arcangelisia flava Merr.) As a medicine for various diseases. Ethnoscience means more or less knowledge possessed by a nation or more precisely a certain ethnic group or social group, and then elevated to a proven scientific knowledge. The experiment carried out was the phytochemical test of the Akar Kuning plant extract (Arcangelisia flava Merr.).

\section{Ethnomedicine data collection}

In this study, data were obtained by interview. Interviews were conducted with 3 (three) men aged 48 to 67 years. They are the natives of Palupuh who live in the vicinity of the Nature Reserve where the yellow root plant can be found. The people around this forest are accustomed to using this Akar Kuning as a medicine for various diseases. Salman is one of the local residents who believe / believe in and have used this plant as an upset stomach and tumor medicine and feel the effects or benefits of the Akar Kuning plant (Arcangelisia flava Merr.). The benefits that have been felt by Mr. Salman after consuming this Akar Kuning plant are the complaints of gastric pain he suffered slowly reduced and healed. This was also felt by other respondents, where their tumors disappeared

This research is an ethnomedic research, which is research whose data is obtained through face-to-face interviews. ${ }^{11}$ The focus of this research includes: (1) the local name Akar Kuning (Arcangelisia flava Merr.); (2) plant characteristics; (3) the use of Akar Kuning plants for local communities; (4) how to make extract from Akar Kuning; (5) additives for extract making. In addition, the investigation is also based on data from the results of the antibacterial activity test against Bacillus subtilis and Escherichia coli.

\section{Phytochemical test}

The steps of this research are phytochemical test and bioactivity test of Escherichia coli root extract (gram negative bacteria). The phytochemical test procedure includes several steps. First, identification of alkaloids using Mayer and Dragendorf reagents. The extract, as a result of isolation using methanol as a solvent, was shaken. If a white or orange-red precipitate is formed after Dragendoft reagent is added, it means that Akar Kuning extract (Arcangelisia flava Merr.) Contains Alkaloids. Second, identification of steroids and terpenoids using Liberman Buchard. If red or purplish-red fog forms, then Akar Kuning isolate (Arcangelisia flava Merr.) Contains terpenoids, and if green or bluish-green mist forms, Akar Kuning isolate (Arcangelisia flava Merr.) Is holding steroids. Third, flavonoid test by inserting a few drops of the water fraction of Akar Kuning isolate (Arcangelisia flava Merr.) into a test tube, then adding Mg metal powder and a few drops of concentrated $\mathrm{HCl}$. If it turns pink to red (except for isoflavones), then the isolates carry flavonoids. Fourth, phenolic identification by adding a few drops of the water fraction of the Akar Kuning isolate (Arcangelisia flava Merr.) Into a test tube, then adding a few drops of $\mathrm{FeCl} 3$. If it turns blue or purplish-blue, the isolate is declared phenolic-positive. Finally, identification of saponins by inserting $1 \mathrm{~mL}$ of water fraction of Akar Kuning isolate (Arcangelisia flava Merr.) Into a test tube then shaken for 1-2 minutes. If temporal foam (which lasts about 5 minutes) forms, the isolate is saponin-positive.

\section{Data analysis}

The research data obtained through interviews with sources were analyzed. The data was then reconstructed based on Hempel. ${ }^{12}$ To strengthen the reconstruction, data from the extract bioactivity test results against Bacillus subtilis and Escherichia coli are needed. Then conclusions are made based on the experimental results.

Jisana mentions that everyone involved in the consumption process is a consumer. ${ }^{12}$ In Law Number 8 of 1999 article 1 paragraph 2 concerning consumer protection, that consumers are users of goods or services available in society, both for the interests of themselves, their families, other people, and other creatures and not for sale. Consumer behavior is the study of processes involved when individuals or groups choose, buy, use, or manage products, services, ideas or experiences to satisfy consumer needs and wants. ${ }^{13}$

\section{RESULTS AND DISCUSSION}

\section{Reconstruction of scientific knowledge based on public trust}

After the research team conducted interviews with several respondents in locations where the Akar Kuning was found found in Palupuah, Kab. Agam. The observation image is arranged in Figure 1. The observation pictures are arranged in Figure 1.

The resource person answered questions based on his knowledge, namely the local name of Akar Kuning (Arcangelisia flava Merr.) Plant characteristics, the use of the Akar Kuning plant for the local community, how to make extracts from Akar Kuning and additives for making extracts. The results of interviews with resource persons are presented in Table 1.

The results of the interviews as presented in Table 1 explain that the community consumes Akar Kuning by brewing or boiling the stem and drinking it as tea. The tea extracted from the Akar Kuning plant has a yellow color. In a scientific context, this process is referred to as a maceration process. To treat stomach pain, the dose of Akar Kuning boiled water is drunk every day until it heals. Akar Kuning is shown in Figure 2.

In previous studies, it was found that the Akar Kuning (Arcangelisia flava Merr) contains chemical compounds, including saponins, flavonoids and tannins, besides that the roots also contain glycosides and alkaloids, especially the isokuinolin group, namely berberine, jatrorizin, and palmatin. There are also some minor alkaloids such as columbamine dehidrokoridalmin, homoaromolin and talifendin, and fibraleucin terpenes, and fibraurin has several activities such as 


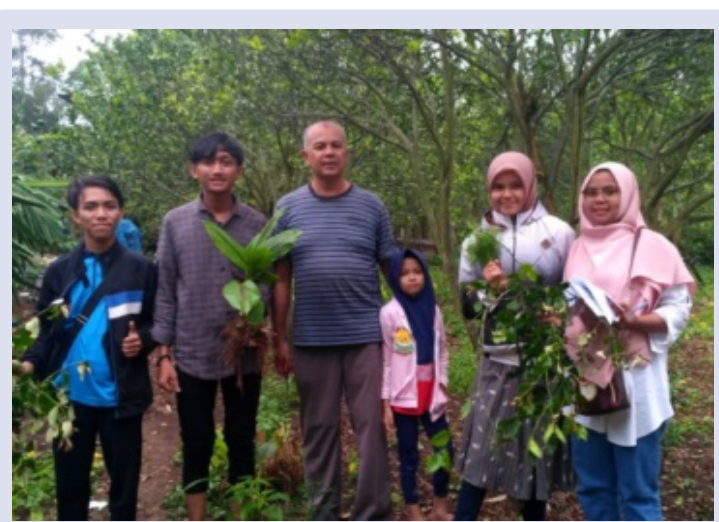

Figure 1: The research team and resource.

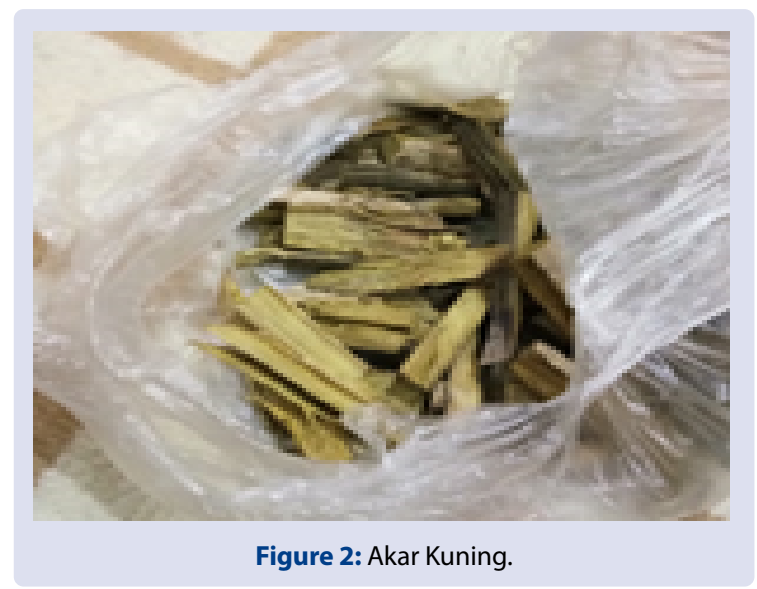

antifungal, antiasma, antibacterial, anti-tumor, anti-malarial and antiinflammatory. ${ }^{13}$

In Indonesia, this plant has various names, including Tali Uning, Oyod Sirawan, and Katola. ${ }^{14}$ Generally, people of Southeast Asia use this plant as traditional medicine, including to treat digestive disorders and as an anti-diarrhea and anti-bacterial which is significant for bacteria. ${ }^{15}$

In the Southeast Sulawesi area, this decoction of A. flava stems is used as an anti-diarrheal with very visible properties. This is caused by the chemical compounds contained in A. flava, namely glycosides and alkaloids, especially the isokuinolin group, namely berberine, jatrorizin, and palmatin. ${ }^{13}$ Furthermore, researchers from Taiwan reported that berberine, jatrorizin, and palmitin contained in the ethanol extract of Mahonia oiwakensis Hayata, were shown to inhibit inflammation in test animals induced by acetic acid, formalin, and carrageenan. ${ }^{16}$

\section{Phytochemical test results}

The steps of this research were phytochemical test and bioactivity test of Akar Kuning extract against Bacillus subtilis (gram positive bacteria) and Escherichia coli (gram negative bacteria). The results of this study are then compared with previous studies to produce a reconstruction of established scientific knowledge.

The phytochemical test procedure includes several steps. First, identification of alkaloids using Mayer and Dragendorf reagents. The extract, as a result of isolation using methanol as a solvent, was shaken. If a white or orange-red precipitate is formed after Dragendoft reagent is added, it means that Akar Kuning extract (Arcangelisia flava Merr.) Contains Alkaloids. Second, identification of steroids and terpenoids using Liberman Buchard. If red or purplish-red fog forms, then Akar Kuning isolate (Arcangelisia flava Merr.) Contains terpenoids, and if green or bluish-green mist forms, Akar Kuning isolate (Arcangelisia

Table 1: Interview results.

\begin{tabular}{|c|c|c|c|}
\hline No. & Focus Question & Informant's Answer & Result of reconstruction of scientific knowledge \\
\hline 1. & The local name of Akar kuning & Akar Kuning (Arcangelisia Flava Merr) & \\
\hline 2. & Characteristics of Akar Kuning plants & $\begin{array}{l}\text { Leaf: oval with five leaf bones at the base } \\
\text { Leaf Color: green } \\
\text { Flower: appears on the axillary leaves and on the trunk } \\
\text { Flower Color: yellow. } \\
\text { Root: roots creeping up and wrapped around the stem. }\end{array}$ & \\
\hline 3. & $\begin{array}{l}\text { The use of Akar Kuning plants for the } \\
\text { community }\end{array}$ & $\begin{array}{l}\text { As a jaundice, anti-malaria, cancer drugs. } \\
\text { People usually use it once a day until the disease is cured, if the } \\
\text { illness is severe, you can drink it } 2 \text { times a day. This rule applies to } \\
\text { all diseases. }\end{array}$ & $\begin{array}{l}\text { Akar Kuning (Arcangelisia Flava Merr) contains } \\
\text { chemical compounds, including saponins, }\end{array}$ \\
\hline 4. & $\begin{array}{l}\text { The part where the Akar Kuning plant } \\
\text { is a traditional medicine }\end{array}$ & Root & $\begin{array}{l}\text { flavonoids and tannins, besides that the roots also } \\
\text { contain glycosides and alkaloids, especially the }\end{array}$ \\
\hline 5. & $\begin{array}{l}\text { How to make herbal extracts or } \\
\text { products from Akar Kuning }\end{array}$ & $\begin{array}{l}\text { In making extracts, the ingredients used are the roots, for the } \\
\text { process as follows: } \\
\text { 1. Cut the Akar Kuning as big as the index finger } \\
\text { 2. Then dry the Akar Kuning in the sun } \\
\text { 3. After the Akar Kuning are completely dry. } \\
\text { 4. Next, make the extract by boiling water until it boils until the } \\
\text { water turns yellow } \\
\text { 5. If you boil } 2 \text { cups of water, the boiled water will later become } \\
1 \text { cup. }\end{array}$ & $\begin{array}{l}\text { isokuinolin group, namely berberine, jatrorizin, } \\
\text { and palmatin. There are also several minor } \\
\text { alkaloids such as columbamine dehydrocoridalmin, } \\
\text { homoaromolin and talifendin, as well as fibraleucin } \\
\text { terpenes, and fibraurin which have several activities } \\
\text { such as antifungal, antiasma, antibacterial, anti- } \\
\text { tumor, anti-malarial and anti-inflammatory (Singh, } \\
\text { A., S. Duggal, N. Kaur \& J. Singh. 2010) }\end{array}$ \\
\hline 6. & $\begin{array}{l}\text { How to use herbal extract from the } \\
\text { Akar Kuning [mixed with anything] }\end{array}$ & $\begin{array}{l}\text { The way to use it is as follows: } \\
\text { 1. Boil } 1 \text { liter of water } \\
\text { 2. Put } 10 \text { grams of Akar Kuning without any mixture } \\
\text { 3. Wait for the water to turn yellow } \\
\text { Note: consumed in the morning and evening after meals, the use } \\
\text { of Akar Kuning as medicine depends on the type of illness you are } \\
\text { suffering from. }\end{array}$ & \\
\hline
\end{tabular}




\begin{tabular}{|c|c|}
\hline $\begin{array}{l}\text { Community behavior patterns } \\
\text { in conserving or protecting Akar } \\
\text { Kuning crops / forests } \\
\text { (Care and love the environment) }\end{array}$ & $\begin{array}{l}\text { Currently, public knowledge is not sufficient in terms of protection. } \\
\text { According to informants who know the exact area of this Akar } \\
\text { Kuning plant in Palupuah and Rimbo Panti, the existence of this } \\
\text { s tree is quite a lot in the surrounding forest along with Bajakah. } \\
\text { However, what is very worrying at this time is that there have } \\
\text { been exploitation actions against this medicinal plant. This can be } \\
\text { seen from the large number of orders for Akar Kuning plant Akar } \\
\text { Kuning by India and the local community simply removing these } \\
\text { Akar Kuning without thinking about the long-term impact that will } \\
\text { arise if these Akar Kuning plants continue to be sent abroad. }\end{array}$ \\
\hline $\begin{array}{l}\text { How to propagate Akar Kuning plants } \\
\text { [nursery] }\end{array}$ & $\begin{array}{l}\text { For nurseries that have never been done in the area around the } \\
\text { research location, this is because the community still thinks that } \\
\text { the Akar Kuning will always be available and will not run out. }\end{array}$ \\
\hline $\begin{array}{l}\text { Experience using the Akar Kuning } \\
\text { plant as medicine }\end{array}$ & $\begin{array}{l}\text { Based on the experience of the informant after consuming the } \\
\text { extract from the Akar Kuning plant, it was known that the stomach } \\
\text { disease suffered was slowly decreasing and within } 2 \text { months it was } \\
\text { declared cured. Not only curing stomach pain, but the benefits were } \\
\text { also felt for tumors, based on the informant's explanation within } 3 \\
\text { months of the lumps on his body. already lost. }\end{array}$ \\
\hline
\end{tabular}

Address : Palupuah, Kab. Religion

Age $\quad: 48-67$ years

flava Merr.) Is holding steroids. Third, the flavonoid test by inserting a few drops of the water fraction of the Akar Kuning isolate (Arcangelisia flava Merr.) Into the test tube. then add Mg metal powder and a few drops of concentrated $\mathrm{HCl}$. If it turns pink to red (except for isoflavones), then the isolates carry flavonoids. Fourth, phenolic identification by adding a few drops of the water fraction of the Akar Kuning isolate (Arcangelisia flava Merr.) Into a test tube, then adding a few drops of $\mathrm{FeCl} 3$. If it turns blue or purplish-blue, the isolate is declared phenolic-positive. Finally, identification of saponins by inserting $1 \mathrm{~mL}$ of water fraction of Akar Kuning isolate (Arcangelisia flava Merr.) Into a test tube then shaken for 1-2 minutes. If temporal foam (which lasts about 5 minutes) forms, the isolate is saponin-positive. Fourth, phenolic identification by adding a few drops of the water fraction of the Akar Kuning isolate (Arcangelisia flava Merr.) Into a test tube, then adding a few drops of $\mathrm{FeCl} 3$. If it turns blue or purplish-blue, the isolate is declared phenolic-positive. Finally, identification of saponins by inserting $1 \mathrm{~mL}$ of water fraction of Akar Kuning isolate (Arcangelisia flava Merr.) Into a test tube then shaken for 1-2 minutes. If temporal foam (which lasts about 5 minutes) forms, the isolate is saponin-positive. Fourth, phenolic identification by adding a few drops of the water fraction of the Akar Kuning isolate (Arcangelisia flava Merr.) Into a test tube, then adding a few drops of $\mathrm{FeCl} 3$. If it turns blue or purplish-blue, the isolate is declared phenolic-positive. Finally, identification of saponins by inserting $1 \mathrm{~mL}$ of water fraction of Akar Kuning isolate (Arcangelisia flava Merr.) Into a test tube then shaken for 1-2 minutes. If temporal foam (which lasts about 5 minutes) forms, the isolate is saponin-positive. Saponin identification by inserting $1 \mathrm{~mL}$ of water fraction of Akar Kuning isolate (Arcangelisia flava Merr.) into a test tube then shaking it for 1-2 minutes. If temporal foam (which lasts about 5 minutes) forms, the isolate is saponin-positive. Saponin identification by inserting $1 \mathrm{~mL}$ of water fraction of Akar Kuning isolate (Arcangelisia flava Merr.) into a test tube then shaking it for 1-2 minutes. If temporal foam (which lasts about 5 minutes) forms, the isolate is saponin-positive.

A series of laboratory work was carried out to provide scientific explanations for indigenous people's beliefs about Akar Kuning as a cure for various diseases.

\section{Scientific explanation of indigenous people's beliefs about Akar Kuning (Arcangelisia flava Merr.)}

Indigenous people's beliefs about Akar Kuning (Arcangelisia flava Merr.) As a medicine for various diseases can be explained scientifically based on the data that has been obtained.
Table 2: Antibacterial activity test results.

\begin{tabular}{cccc}
\hline \multirow{2}{*}{ Sample } & \multirow{2}{*}{ Deuteronomy } & \multicolumn{2}{c}{ Inhibition zone diameter } \\
\cline { 3 - 4 } & & Bacillus subtilis & Eschirichia coli \\
\hline Water + Akar & 1 & $9 \mathrm{~mm}$ & $9.75 \mathrm{~mm}$ \\
Kuning & 2 & $11 \mathrm{~mm}$ & $7.75 \mathrm{~mm}$ \\
Akar Kuning & 1 & $14.5 \mathrm{~mm}$ & $9.5 \mathrm{~mm}$ \\
Water Methanol & 2 & $10.25 \mathrm{~mm}$ & $8.5 \mathrm{~mm}$ \\
$70 \%$ & 1 & $12.75 \mathrm{~mm}$ & $10.5 \mathrm{~mm}$ \\
Benzene + Akar & 2 & $10.75 \mathrm{~mm}$ & $11 \mathrm{~mm}$ \\
$\quad$ Kuning & & &
\end{tabular}

Table 3: Inhibition zone diameter category.

\begin{tabular}{cc}
\hline Diameter & Power of Inhibition \\
\hline$\leq 5 \mathrm{~mm}$ & Weak \\
$6-10 \mathrm{~mm}$ & Moderate \\
$11-20 \mathrm{~mm}$ & Strong \\
$\geq 21 \mathrm{~mm}$ & Very strong
\end{tabular}

Antibacterial activity test was carried out twice against Bacillus subtilis and Escherichia coli. Observations were made on three mixtures of Akar Kuning, namely water Akar Kuning, 70\% methanol Akar Kuning, and benzene Akar Kuning. In the water Akar Kuning sample, the inhibition diameter against Bacillus subtilis was $9 \mathrm{~mm}$ and $11 \mathrm{~mm}$ and the Escherichia coli bacteria were $9.75 \mathrm{~mm}$ and $7.75 \mathrm{~mm}$. Furthermore, in the Akar Kuning sample of $70 \%$ methanol, it was found that the inhibition diameter against Bacillus subtilis was $14.5 \mathrm{~mm} 10.5 \mathrm{~mm}$ while the inhibition diameter against Escherichia coli was $9.5 \mathrm{~mm}$ and $8.5 \mathrm{~mm}$. And finally in the yellow benzene root sample, the inhibition diameter against Bacillus subtilis was $12.75 \mathrm{~mm} 10.75 \mathrm{~mm}$, while the inhibition diameter against Escherichia coli was $10.5 \mathrm{~mm}$ and $11 \mathrm{~mm}$. The value of inhibition generated in each sample has its own meaning. The width of the diameter of the inhibition zone formed can be used as a parameter to determine the strength of the bioactive compounds contained in the Akar Kuning extract.

Judging from Table 2, for samples of water Akar Kuning s have strong antibacterial activity against Bacillus subtilis and have moderate antibacterial activity against Escherichia coli bacteria. Furthermore, for the Akar Kuning sample, $70 \%$ methanol had strong antibacterial activity against Bacillus subtilis and had moderate antibacterial activity against Escherichia coli bacteria. And finally, for the yellow benzene 
root sample, it has strong antibacterial activity, both against Bacillus subtilis and against Escherichia coli.

Based on the inhibition zone diameter category table, it can be said that the wider the formed inhibition zone indicates the greater the strength of bioactive compounds in inhibiting bacterial growth. ${ }^{17}$ According to Setiabudy, a certain antibacterial agent can increase its activity if its antibacterial level is increased beyond the minimum inhibitory level. ${ }^{18}$

It is known that the stems of this Akar Kuning plant contain protoberberine alkaloid compounds consisting of berberine and palmatin. The alkaloid protoberberin was stated to be active as an antibiotic against Gram-positive and Gram-negative bacteria, where in the study that acted as gram-positive was Bacillus subtilis and the one acting as gram-negative was Escherichia coli. ${ }^{19}$ Alkaloid compounds (berberine and columbine) can interfere with the formation of cross bridges of peptidoglycan components in bacterial cells, so that the cell wall layer is not formed completely and causes death in these cells. ${ }^{20}$ That is a scientific explanation departing from the public's belief that the Akar Kuning plant functions as a medicine for various diseases.

\section{CONCLUSIONS}

Based on the data obtained, it can be concluded that the Akar Kuning plant extract (Arcangelisia flava Merr.) Has bioactive compounds that act as antibacterials and can inhibit bacterial growth.

\section{SUGGESTION}

Based on the results of this study, it can be useful for documenting medicinal plants that have the ability to cure various diseases. For further research, we can look for other plants that have similar properties to the Akar Kuning plant.

\section{REFERENCES}

1. Matsjeh, S. (2009). Pemanfaatan Bahan Alam Nabati Yang Berpotensi Sebagai Bahan Baku Senyawa Obat. Makalah pembicara tamu Seminar Nasional di Fakultas Farmasi Universitas Tanjungpura, 16 Februari 2009

2. Subiandono E, Heriyanto NM. Kajian Tumbuhan Obat Akar Kuning (Arcangelisia flava Merr.) di Kelompok Hutan Gelawan, Kabupaten Kampar, Riau. Buletin Plasma Nuftah. 2009;15:43-4.
3. Amir, H., Murcitro, B. A., \& Kassim, M. (2017). The Potential Use of Phaleria Macrocarpa Leaves Extract As An Alternative Drug For Breast Cancer Among Women Living In Poverty. Asian Journal For Poverty Studies 3(2) , 138 - 145.

4. Sudarsono, Setyowati EP. Pengaruh ekstrak batang larut air kayu kuning (Arcangelisia flava L. Merr) terhadap penghambatan pertumbuhan Candida albicans ATCC 10231 dan Trichophyton mentagrophytes in vitro. Biologi Kedokteran \& Kimia Produk Alami 2014; 3 (1): 15-9.

5. Widyatmoko, D. and F. Zick. 1998. The flora of Bukit Tiga Puluh National Park Kerumutan Sanctuary and Mahato Protective Reserve, Riau, Indonesia. Indonesia Botanis Gardens in collaboration with Yayasan Sosial Chevron dan Texmaco Indonesia.Bhasin, V., Ethno.Med., (2017), 1 (1), 1-20.

6. Sudarmin, Zaenuri, Sumarni, W. (2019). Pengembangan Model Pembelajaran Sains Berbasis Kearifan Lokal. Laporan Penelitian. Universitas Negeri Semarang

7. Kartawinata, K. (2010). Dua Abad Mengungkap Kekayaan Flora dan Ekosistem Indonesia. Dalam: Sarwono Prawirohardjo Memorial Lecture X. LIPI. 23 Agustus 2010. Jakarta.

8. Walujo, E., (2013). Etnofarmakologi: Saintifikasi Pengetahuan untuk Pengembangan Industri Kimia dan Farmasi di Indonesia.

9. Manar, PA, (2018). Pengetahuan Etnofarmakologi Tumbuhan Alang-Alang (Imperatacylindrica L.) oleh Beberapa Masyarakat Etnik di Indonesia, TM Conference Series 01 (2018): 114-116, online:https: // talenta confseries .usu. ac.id.

10. Akbulut, S., \& Bayramoglu, M. (2013). The Trade and Use of Some Medical and Aromatic Herbs in Turkey. Ethno Med, 7(2\}, 67-77

11. Hempel, C. (2014). Scientific Explanation, Stanford Encyclopedia Philosophy

12. Singh, A., S. Duggal, N. Kaur \& J. Singh. 2010. Berberin: alkaloid with wide spectrum of pharmacological activities. Journal of Natural Product 3: 64-75.

13. Artyani T. 2014. Efek antidepresan ekstrak larut air akar kuning Arcangelisia flava (L.) Merr pada mencit Balb-C ditinjau dari immobility time dengan metode forced swim test. Skripsi. Fakultas Farmasi Universitas Gadjah Mada.

14. Larisu, M. A. 2011. Kajian ilmiah air rebusan batang katola (Arcangelisia flava (L) Merr) obat tradisional diare berdarah masyarakat Kabupaten Muna Sulawes Tenggara. Tesis. Program Pascasarjana Fakultas

15. Chao, J, J.W. Liao, W.H. Peng, M.S. Lee, L.H. Pao \& H.Y. Cheng. 2013 Antioxidant, analgesic, antilnflammatory, and hepatoprotective ffects of the ethanol extract of Mahonia oiwakensis stem. Int. J. Mol. Sci. 14: 2928-2945

16. Lay, Bibiana W, Hastowo, Sugyo. Mikrobiologi. Jakarta: Rajawali Press, 1992; p. 32.

17. Setiabudy R. Antimikroba. In: Tanu I, editor. Farmakologi dan Terapi (5th ed) Jakarta: EGC, 2008; p. 585

18. Yuliasri J, Praptiwi, Fathoni A, Agusta A. Bioproduksi Floroglusinol Oleh Jamur Endofit Coelpmyecetes Afas-F3 yang Diisolasi dari Tumbuhan Archangelesia flava L. Merr. Berk Penel Hayati. 2011;16:169-72.

19. Robinson T. Kandungan OrganikTumbuhan Tinggi. Bandung: ITB; 1995; p. 281-5. 


\section{GRAPHICAL ABSTRACT}

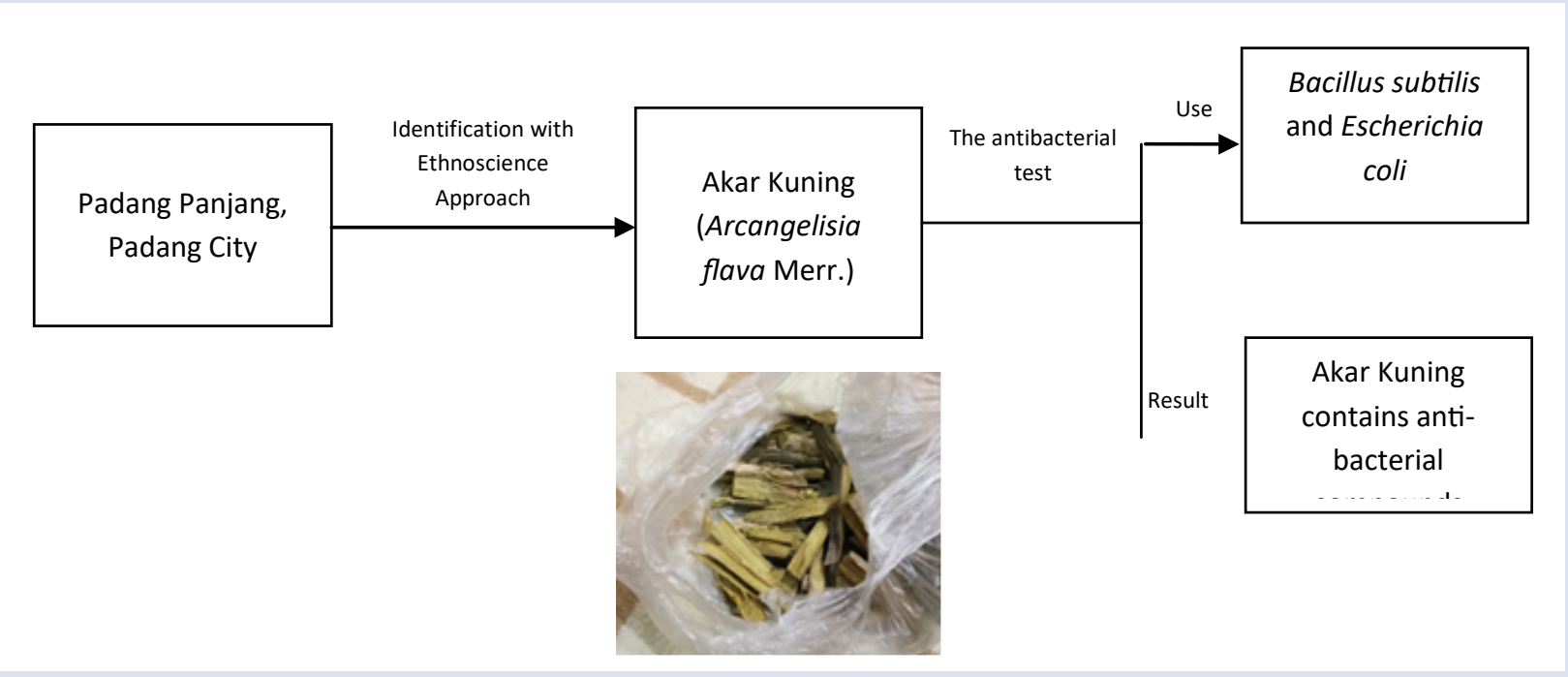

\section{ABOUT AUTHORS}

- Dr. Skunda Diliarosta, M.Pd; Currently as lecturer at Mathematics and Science Faculty, Padang State University. Doctoral program graduated from Padang State University. The research and expertise are in environmental and science education. One of the new research is about the effect of agricultural extension for improvement environmental behavior by vegetable farmer.

- Sudarmin; Currently as lecturer at Chemistry Department, Mathematics and Natural Sciences Faculty, Semarang State University

- Annisa Efendi; Students of Natural Science Education Padang State University 2017, Graduated from ES 09 AirTawar Barat, JHS 13 Padang and SHS 7 Padang. The research have been followed about Ethnomedicine study on medicinal plants used by communities in West Sumatra, Indonesia

- Dwisari Dillasamola; Currently as lecturer at Pharmacology department, Faculty of Pharmacy, Andalas University.

- Biomechy Oktomalioputri; Currently as lecturer at Histology Department, Faculty of Medicine, Andalas University

- Rehani Ramadhani; Students of Natural Science Education Padang State University 2017, Graduated from ES 24 Ujung Gurun, JHS 13 Padang and SHS Ekasakti Padang. The research have been followed about Integration of Food safety and health consciousness in Padang and actives to be part of girlscout UNP.

Cite this article: Diliarosta S, Sudarmin, Efendi A, Dillasamola D, Oktomalioputri B, Ramadhani R. Reconstruction and Scientific Explanation of Akar Kuning (Arcangelisia flava Merr.) From West Sumatra as Ethnomedicine and Source of Science Learning. Pharmacog J. 2021;13(1): 206-11. 